hold enuf to know better and even servents thats got ard work to do, will ware there stays tite has much as evver, tho sum peepel says peepel dont lace tite now. $i$ wish to goodness Sir, the Doctors woud make them ashamed of it. then Sir, wen the ladys gets nervus complantes i have known the Docter tell them to take eksersise, but he does not insist upon it being of a rousing sort. if it does not ster them up and put them in a perspirashun it ardly does a bit of good. exkuse me Sir for speking so plain, but $i$ ave seen it so often it maks me indigenant to see the foolish young things a throing away themselvs and there mammas inkurriging of them, and the Docter thinking is orders his minded wen the sens of them his never understud at all. Wen the fammily is rich the Docter horders riding and that does well, eksep that there jakkets is so tite, but wen the Docter knows the ekspense his to grate, he tels them to walk, and so they do, but at such a pase that if thay went til thay dropt thay would nevver perspire the leest, and thay are scarse any the better. Why dont thay play games Sir, or pull an ore hon the water? My young ladys did Sir, and it done them a world of good, but the Docter never orders it, and the ladys thinks it ard bekos they ave nevver tryed. but the stays Sir is worst of all; eksersise nor nothin will nevver do no good till thay are left of, and thay nevver will til the Docters set there face agen them. it is no good only riting books agin them, thay shoud insist on always knowing just as regler as they questiun about any thing els. i knew a young lady Sir, who had a delliket chest, and she come of a fammily that was all subject to consumtion that began with spitting blood. She used to flush very much at times, tho in general she was pale, and wen she was flushed her chest was stuffy like and unesy. She was not one of my young ladys or i shoud ave seen to it long before, but she were staying in the house, and one day wen she semed so poorly, i made bold and says to her, "Miss do you ware your stays tite?" "No," she says, " $\mathrm{i}$ dont, but why do you hask ?" i says, "i ope no offense Miss, it is bekors you seem to me to brethe so opprest." She was a nice young lady Sir, and she let me see how er stays was fassened, and to be sure they was not to be calld tite, nothing like what $i$ ave known manny, but still they did pres a littel, and she ad none to much room in the make of her chest. The end was Sir, i got her to leve them of and ware a jersey what are made for ladys, that she nite not mis the warmth, and i nevver see her flush like that Sir agin. if stays like ers done all that arm, it must be ten times wors were thay are raly tite. i cannot tell Sir what a dele of good you woud do if you woud but ber the meddicle gentelmen to see to those things always wen thay attend ladys; it is nere always the same Sir wen it is fainting and nervus complantes, and they are so angry if a nurse says a word, but they woud mind the Docter Bir.

i ope you will ave a littel more pashens Sir, just to say somethin about confinements. it often appens that the furst staige of labor is very tedius, and the sufering very grate, and yet all is hover well and quick wen once the change of panes cums on. in every case that $i$ have beên with so as $i$ could know what was the ladys state during the few months previus, it as always ben the same, that she coud ardly get about much, and suferd all maner of il-conweniens, and all the wate of the figger was to much down and to much hover like, and they diskribe the panes when they come hon as being for a long time almost all in the back, not the thro and thro direckt downwurds pane that it is in a tollerable quick labor. i do reelly think Sir that many a Docter never suspecks the cause of this- $-i$ scarse evver knowd a Docter menshun it and never red it in a book. i have seen the remmedy spoken of in a book, but not the cause of the mischef. it is the wate of the pettycotes. You cannot think Sir what pownds and pownds a ladys pettycotes ways, and even poor peoples is sometimes bad enuf, but not nere so bad as a ladys. if you was to take them up in your hand hall of a bunch you would wunder i'm sure Sir owhevver they can bare them. the way Sir that $i$ ave got some ladys to do as been to ware stays very loos, but long in frunt, then below that a brord elastick band which confines the botom of the stays, which shoud ave a thin steel all down the frunt--the band both supportes the wate of the body, and makes the steel keep of some of the wate of the close. $i$ ave nevver knowd a lady unabel to get about, even to the very last, or ave tedius labor in the early stage. Diffikult delivvery $i \mathrm{know}$ is quite another thing, and is from other causes - wen she ad drest like that, not if she ad ad herver so manny bad times befor, and wen thay wont do it Sir they go on just the same time after time. it is a hexcellant contryvense that some of the meddicle gentelmen use Sir, of a band round the body at the time of labour, wich they draw up wen every pain comes, but it would scarse evver be wanted if ladys would but do as I say beforhand. Sir, will you beg the meddicle gentelmen to horder it wen they attend ladys before thay are confined. The pettycotes is a most orrible wate; a band of callico woud be better than nothing for pore peeple who cant by elastick. One more thing Sir, $i$ ope your pashens is not wore out. After confinement the pashent is bandiged up, but $i$ know that they hoffen leve it of in a very few days without the Docter hasks sometimes about it; but ware $i$ attend Sir, $i$ always makes them ware it middling tite, until all discharge as stopt, and $i$ beleive Sir that is what the Docters wish, for they always says i am rite, but some nurses dont mind it, and Docters dont think to ask, and many ladys wont ave it without they are made, and then comes on all kinds of weeknes, all for want of that simpel thing.

i am no great scolard $S i r$, or $i$ shoud ave rote this myself, and then praps $i$ shoud have said it better, but $i$ cant spel very well, but $i$ ope my dauter as rote it cleer, for $i$ gave her good scooling. i remane Sir, your obeedent umble servent, A NOLD NURSE.

Septhember, 1856 rote on one side-i

they say what is for print should only be rote
pe this is done rite; it takes a dele of paper.

\section{MEETINGS OF UNION MEDICAL OFFICERS.}

AT a meeting of the medical officers of the Warwick Union, at the Warwick Arms Hotel, Warwick, on the 6th November 1S56, present, Messrs. Watson, Blenkinsop, Clarke, and Tibbitts, being the whole of the medical officers of that union, Mr. Blenkinsop in the chair, it was resolved-

1. That the thanks of this meeting be tenclered to $\mathbf{M r}$. Griffin, of Weymouth, for his exertions in aid of a more equitable remuneration of the services of the union medical officers.

2. That it is the opinion of this meeting that the medical officers of workhouses should be paid the same fees for extra services as those awarded to the district medical officers for extra cases.

3. That as the present salaries of union medical officers bear no equitable proportion to the duties they are called on to perform, it is most desirable that their amount should be increased.

4. That a subscription of 5s. from each medical officer of this union be forwarded to Mr. Griffin, for defraying the expenses of the movement.

5. That a copy of these resolutions be forwarded to $\mathrm{Mr}$. Griffin and the medical journals.

6. That the medical officers of this union pledge themselves to ask the assistance and support in the House, of the members of Parliament of the county and borough.
H. BLENKINSOP.
J. Clarke

\section{W. WATSON.}
J. TIBbitTs.

Officers from the following unions have joined the Poor-law Medical Reform Association since the last report was printedGreat Yarmouth, King's Lynn, Ripon, Clun, Warwick, Daventry, and Woodbridge.

\section{THE REGISTRAR-GENERAI AND MEDICAL OFFICERS OF HEALTH.}

\section{General Register Office, Somerset House,} November 15 th, 1856.

STr,-Knowing that it is important that you should possess at an early period, correct information of all deaths registered in the district of which you are medical officer of health, and anxious that no unnecessary expense should be incurred in obtaining this information, I intend to transmit gratuitously to you from this office, on Wednesday, the 7th of January, 1857, a return of the deaths registered in your district in the previons week, and I shall continue to do so on every succeeding Wed. nesday.

I will thank you carefully to preserve these weekly manu script returns which you will receive from me, so that they may at a future period, if necessary, be easily referred to.

In order that you may be able to ascertain with exactness the mortality in your district, I recommend that at stated periods you should put yourself in conmunication with those medical officers of health, in whose districts public institutions are situated in which persons die who have been removed thereto from your district, that you may ascertain their previous residences.

If the vestry, or other local authorities, have made an 
arrangement with the registrars of births and deaths for furnish ing you with particulars respecting the deaths registered, I will thank you to communicate to such authorities my intention in this respect, in order that they may adopt such measures as, under the altered circumstances of the case, may seem to them expedient.

I have the honour to be, Sir, your faithful servant, GEoRgE GRAHAM, Registrar-General

Medical Officer of Heaith for

\section{Altricat allérs.}

Apothecaries' Hall. - Names of gentlemen who passed their examination in the science and practice of Medicine, and received certificates to practise, on

Thursday, November $13 t h, 1856$.

Down, JoHn Langdon Haydon, Torpoint, Cornwall.

Groom, William, Wisbech, Cambridgeshire.

Howeld, GrifFrtH, Llanelly, Carnarvon.

Proctor, J AMes, Congleton.

RoBerts, Tromas Lewrs, Blaengadi, Aberystwith.

Woodrouse, Wilduam, Norwich.

The following is a list of the names of the gentlemen who passed their examination in Classics and Mathematics, on

Tuesday and Wednesday, the 18 th and $19 t h$ inst.

Barron, Edward, St. Thomas'-street, Southwark.

Buzzard, Frank, lutterworth.

Caldweld, Winlaam, Harleyford-place, Kennington.

Custance, James, Sutton, Isle of Ely, Cambridgeshire.

Davy, Richard, Chumleigh, Devon.

EuLIS, EDward, Howland-street, Iondon.

Evans, Nichold, Stoke Newington.

FagGe, Frederick, Hythe, Kent.

Foster, Phrmip, Leeds.

Gannon, John P., Hastings, Sussex.

GODDARD, EugEnE, St. John's-road, Clerkenwell.

Grabuam, Charcess, Lonsdale-square, Islington.

Hett, ARTHuR, Brigg, Lincolnshire.

HugHes, Rrcrand, Fenchurch-street.

$J_{\text {ACKSON, J }}$ AMES CoLE, Sawbridgeworth, Herts.

JoNEs, WaLTER, Queen's College, Birmingham.

Mason, Thomas Edward, Broad-street, Deal.

MAY, JOSEPH, Stoke, Devonport.

Moore, EDwin, Chapel-street, Salford.

Parsor, Edward, Liskeard, Cornwall.

Roe, Edwin Hodgsoy, Eccles.

RyLaNd, Thos. EDWARD, Calthorpe-street, Birmingham.

Sharp, Edwakd, Truro, Coenwall.

Tayler, Willtam George, Westmeon, Hants.

TerRy, Septimus, Market-square, Northampton.

Walls, Charles, Queen's College, Birmingham.

Watson, Forbes, Raymond Hotel, London Wall

Wirson, Henry Octavius, Richmond-terrace, Bristol.

Woophams, T. A., Bedford-street, Strand.

Appointment.-Dr. H. Hannotte Vernon has been appointed. Physician to the Blenheim-street Dispensary.

Portrait of Sir B. C. Brodie.-An excellent photographic likeness of this distinguished surgeon has just been published by Messrs. Maull and Polyblank.

Hospital for Consumption and Diseases of the CHest, Brompton. - This hospital has received the recognition of its practice by the Apothecaries' Company, Army, Navy, East India Company, \&ce., as a part of the curriculum of any student who may desire to attend it.

Medical Representatives in Parliament.-It is gratifying to observe by the public papers that at a late meeting of the Leitrim Club, Mr. Brady's re-election for the county was decided. Mr. Brady has always been an unflinching advocate of the rights and privileges of his brethren, and he has done honour to the profession of which he is a member and a worthy representative.

Quenn's College, Birmingham.-It must be gratifying to the friends of Qneen's College, Birmingham, to learn that the Rev. Chancellor Law has resumed the office of viceprincipal, and was received with a most hearty welcome by a full Board assembled on Wednesday, the 12th instant. The Right Hon. the Earl of Warwick and Lord John Scott have been elected on the Council to fill up the vacancies which have occurred, and have accepted office. Mr. Thomas Upfill has been unanimously appointed treasurer. The Earl of Bradford has presented a donation of $£ 10$; Lord Redesdale, $£ 10$; Lord Willonghby de Broke, $£ 10$; Beriah Botfield, Esq., £10; Digby Wingfield Digby, Esq., £10; and Edward Townsend Cox, Esq., £10, towards the new buildings. A valuable collection of objects of natural history, from South Africa, has been received from that valued friend of the institution, Major-General Whylock, R.M. The Council have selected as the subject of the Warneford prize essays for the ensuing year, "The Ana. tomy and Physiology of the Kidneys." The founder's instructions are-" The interest of $£ 1000$ to be applied for ever for the institution of two prizes, either in equal or unequal amount, as may seem to the trustees most likely to advance the great ends in view, which are to combine religious with scientific studies and pursuits, to make medical students good Christians, as well as able practitioners of medicime and surgery. The compositions written for these prizes to be of a religious as well as scientific nature; the subject to be taken out of any branch of anatomical, physiological, or pathological science, and to be handled in a practical or professional manner, and according to those evidences of facts and phenomena which anatomy, physiology, and pathology so abundantly supply; but always and especially with a view to exemplify or set forth by instance or example, the wisdom, power, and goodness of God, as revealed and declared in Holy Writ." The following is a complete list of the essays which have been written; several of the compositions have been published, and are worthy of being placed alongside the "Bridgewater Treatises":-1849, Roden, Birmingham, "The Valvular Construction of the Veins." 1840, Smith, London, "The Aortic Circulation," 1841, Clay, India, "The Valvular Structure of the Heart." 1842, Male, West Bromwich, "The Anastomoses of Arteries." 1843, Clarkson, Birmingham, "The Nerves of the Chest." 1844, Moore, Bourton-on-the-Water, "The Structure of the Lungs." 1845, Joseph, Tipton; Hughes, Nannerk Rectory; "The Blood." 1846, Masfen, Stafford ; Pemberton, Birmingham; "The Organs of Voice." 1847, Whittle, Leamington; Bird, London; "The Spinal Column." 1848, Lane, Grosmont; Dunn, Ledbury; "The Articulations of the Skeleton." 1849, Stead, Congleton; Mills, Tipton; "The General Anatomy of the Brain." 1850, Roland, India; Blake, Birmingham; Lowe, India, "The General Anatomy of the Spinal Cord." I851, Franks, Whittlesea; Banks, Birmingham; "The Arterial and Venous Circulation of the Brain." 1852, Webb, Wirksworth; Waller, Chesterfield; "The Anatomy of the Fifth Pair of Nerves." 1853, Scofield, Hall Green; Suckling, Birmingham; "The Organs of Taste." 1854, Porter, Peterborough, Heeley, Birmingham; "The Organs of Hearing." 1855, Bond, Weymouth; Neal, Birmingham; "The Organs of Sight." 1856, Bright, Richmond; Greene, Birmingham; "The Organs of Smell."

Heacter of London duRing the Week ending SATURDAY, NOVEMrBeR 15TH. - The deaths registered in London, which in the two preceding weeks were 969 and 1006 , rose in the week that ended last Saturday to $1090,-$ an increase which is usual in this month, proverbially known for bringing with it cold weather and fogs. In the ten weeks corresponding to last week of the years 1846-55 the average number of deaths was 1051 , which, if raised in proportion to increase of population, becomes 1156. The rate of mortality, which now rules, is still below the average. In comparing the results of the last two weeks, the increase shown above will be found to arise chiefly from diseases of the organs of respiration; for the deaths referred to this class have increased from 200 to 258 ; those placed to diseases of the nervous system from 90 to 113 (the special head under which the increase occurs being convulsions of infants); whilst in deaths caused by diseases of the zymotic class there is a decrease from 238 to 212 . The corrected average for diseases of the respiratory organs is 194 ; the mortality (258) from this class, last week, was therefore high; 113 persons, of whom 58 were forty years old and upwards, died of bronchitis; 114 persons, of whom 100 were children, died of pneumonia or inflammation of the lungs. In the zymotic class, typhus or common fever was fatal in 45 cases, scarlatina in 41 , hoopingcough in 40 , measles in 25 , diarrhcea in 25 , croup in 9 , smallpox in only 3 . Ten women died of diseases incidental to childbearing, 4 persons from carbuncle, 1 from neuralgia, 1 from intemperance. Of the whole number of deaths, 552 or rather more than half occurred under 20 years of age; and of 42 which occurred at 80 years or upwards, 6 were those of nonacenarians, of whom the two oldest were 96 and 97 years old, and both widows. Of these 6 persons only 2 were men. 